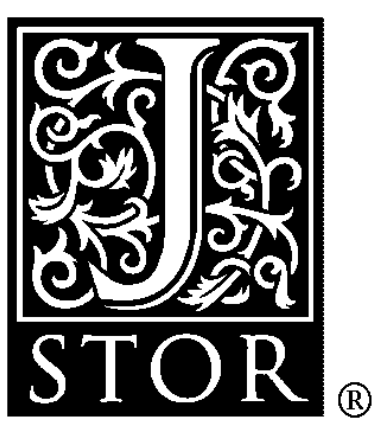

Changes in Light and Nitrogen Availability under Pioneer Trees May Indirectly Facilitate Tree Invasions of Grasslands

Author(s): Evan Siemann and William E. Rogers

Source: The Journal of Ecology, Vol. 91, No. 6 (Dec., 2003), pp. 923-931

Published by: British Ecological Society

Stable URL: http://www.jstor.org/stable/3599678

Accessed: 09/09/2008 12:15

Your use of the JSTOR archive indicates your acceptance of JSTOR's Terms and Conditions of Use, available at http://www.jstor.org/page/info/about/policies/terms.jsp. JSTOR's Terms and Conditions of Use provides, in part, that unless you have obtained prior permission, you may not download an entire issue of a journal or multiple copies of articles, and you may use content in the JSTOR archive only for your personal, non-commercial use.

Please contact the publisher regarding any further use of this work. Publisher contact information may be obtained at http://www.jstor.org/action/showPublisher?publisherCode=briteco.

Each copy of any part of a JSTOR transmission must contain the same copyright notice that appears on the screen or printed page of such transmission.

JSTOR is a not-for-profit organization founded in 1995 to build trusted digital archives for scholarship. We work with the scholarly community to preserve their work and the materials they rely upon, and to build a common research platform that promotes the discovery and use of these resources. For more information about JSTOR, please contact support@jstor.org. 


\title{
Changes in light and nitrogen availability under pioneer trees may indirectly facilitate tree invasions of grasslands
}

\author{
EVAN SIEMANN and WILLIAM E. ROGERS \\ Department of Ecology and Evolutionary Biology, Rice University, Houston, TX 77005, USA
}

\begin{abstract}
Summary
1 The first trees establishing in grasslands may indirectly favour their seedlings in competition with neighbouring herbaceous vegetation by increasing soil fertility with nitrogen-rich litter and by reducing light levels under their canopies. It is predicted that increasing soil nitrogen availability will accelerate invasion of trees by stimulating their growth more than that of herbaceous species. Decreasing light availability is predicted to increase tree invasion by limiting the growth of herbaceous vegetation more than that of trees (competitive release).

2 We tested these predictions using Chinese tallow tree (Sapium sebiferum), which is an aggressive alien invader of grasslands in the southern USA, and Hackberry (Celtis laevigata), which is a native tree common in these grasslands.

3 Nitrogen and light were manipulated in two factorial field experiments in grasslands in Texas, USA. In the first, nitrogen was increased and light was decreased in plots with planted Celtis or Sapium seedlings. In the second experiment, light availability to planted Celtis or Sapium seedlings was increased by holding back prairie vegetation.

4 In the first experiment, growth of Celtis and Sapium seedlings increased with nitrogen fertilization while the above-ground biomass of prairie vegetation did not change. Prairie vegetation biomass decreased and tree seedling growth increased under shading. Sapium's growth increased dramatically in the treatment with combined nitrogen and shade. Sapium survival decreased when shade was applied.

5 In the second experiment, Sapium growth increased with increased light. Thus, increased Sapium growth at low light levels in the shade experiment was probably a consequence of decreased competitive interference from prairie vegetation, rather than better absolute performance of Sapium in low light levels.

6 These results provide evidence for facilitation as a mechanism involved in tree invasions of grasslands. Changes in resource levels, perhaps in combination with other factors, may explain rapid conversion of grassland communities to woodlands after the first pioneer trees are established. The marked response of Sapium to the combination of nitrogen and shade suggests that these positive feedbacks may be particularly strong for this alien plant species.
\end{abstract}

Key-words: Chinese tallow tree, facilitation, light, nitrogen, Sapium sebiferum

Journal of Ecology (2003) 91, 923-931

\section{Introduction}

Invasions of woody plants into grasslands are often slow as the first trees are established, but subsequent displacement of grassland vegetation is rapid (e.g. Bragg \& Hulbert 1976; Scholes \& Archer 1997; Van Auken 2000; Briggs et al. 2002). Abundant local seed input
Correspondence: Evan Siemann (tel. 713348 5954; fax 713 348 5232; e-mail siemann@rice.edu). sometimes plays a role in accelerating invasions by woody species (Archer et al. 1988; Berlow et al. 2002). In such cases, the increasing rate of woody plant expansion is a demographic phenomenon, possibly with relatively constant success on a per seed or seedling basis throughout the conversion phase. However, the rapid increase in woody cover after the earliest stages of invasion may in some cases reflect a positive feedback involving changes in resource conditions that favour woody seedlings in competition with background 
E. Siemann \& W. E. Rogers

(C) 2003 British Ecological Society, Journal of Ecology, 91, 923-931 herbaceous vegetation (Connell \& Slatyer 1977; Li \& Wilson 1998; Wilson 1998). In some cases, the average success of seeds and seedlings of woody plants may increase in combination with higher seed input. In this paper we investigate the role of changing nitrogen and light supply on invasions of tallgrass prairies in the southern United States of America (USA) by the alien Chinese tallow tree (Sapium sebiferum).

Woody plants often produce nitrogen-rich litter that decomposes more rapidly than grass litter in the ecosystems in which they both occur (Cameron \& Spencer 1989; Hibbard et al. 2001). This can elevate available soil nitrogen levels under woody plants compared with parts of grasslands where woody plants are not yet present (e.g. Callaway et al. 1991; Scholes \& Archer 1997; Hibbard et al. 2001). For example, nitrate concentrations in soil under Sapium trees in Texas are approximately double those in neighbouring grasslands (Cameron \& Spencer 1989). Greater nitrogen availability tends to intensify above-ground competition for light and favours woody plants in competition with grasses (e.g. Tilman \& Pacala 1993; Wilson 1993; Grace 1995; Li \& Wilson 1998; Wilson 1998). Further, C3 plants such as Sapium have lower nitrogen use efficiencies and higher nitrogen requirements than $\mathrm{C} 4$ plants such as the perennial bunchgrasses that are abundant in tallgrass prairies (Sage \& Pearcy 1987). However, woody plants need not always have a higher litter nitrogen concentration than that of grasses (Köchy \& Wilson 1997). It has been shown that anthropogenic nitrogen deposition can accelerate invasions of grasslands by alien grasses and herbs (e.g. Huenneke et al. 1990; Bakker \& Berendse 1999; Dukes \& Mooney 1999), and accelerate forest expansion (Köchy \& Wilson 2001). Experimental nitrogen addition has also been shown to speed transition to native forests in infertile grasslands (Tilman 1990), but the possible role of positive nitrogen feedbacks in promoting invasion of grasslands by alien woody species is poorly understood.

As shrubs or trees invade grasslands, they reduce light availability to herbaceous vegetation and woody seedlings once the first woody plants overtop herbaceous plants (Scholes \& Archer 1997; Wilson 1998). For instance, a single 15-year-old Sapium tree in Texas grasslands can reduce light to $7 \%$ of ambient levels in its densest shade, and cast $80 \%$ or greater shade over $30 \mathrm{~m}^{2}$ (E. Siemann \& W.E. Rogers, unpublished data). Wilson (1998) suggested that the shade cast by mature trees may favour their seedlings in competition with grasses by favouring woody plants with low root : shoot ratios over grasses with high root: shoot ratios. This positive feedback could promote rapid grassland-forest transitions. Li \& Wilson (1998) showed that simultaneously shading, increasing water availability and fertilizing with nitrogen favoured woody seedlings in competition with grasses. In addition, because $\mathrm{C} 4$ plants expend additional energy in photosynthesis to avoid photorespiration in hot and/or dry conditions, shaded conditions may favour C3 plants such as Sapium that do not have this additional metabolic cost (Mooney 1972; Lambers et al. 1998).
If Sapium performs better in shaded treatments, it may reflect competitive release (indirect facilitation sensu Levine 1999) but it could also reflect better absolute performance of Sapium in shaded conditions (Goldberg \& Barton 1992; Jutila \& Grace 2002). The latter possibility is not likely because, in general, the earliest woody colonizers perform relatively poorly in low-light conditions (Tilman 1988). Nevertheless, to distinguish between the two explanations for better Sapium performance in low light, we complemented the experiment on the effects of fertilization and shade with one in which we increased light for Sapium seedlings, thereby reducing the extent to which they compete above ground with herbaceous vegetation. If competitive release is the primary cause of a positive response to shade treatments, Sapium should perform better in these high-light, low-competition conditions.

\section{STUDY SPECIES}

The alien Chinese tallow tree (Sapium sebiferum (L.) Roxb., Euphorbiaceae, 'Sapium' hereafter; nomenclature follows Hatch et al. 1990) is invasive in the southern USA (Bruce et al. 1997; Grace 1998). It grows rapidly, has oil-rich seeds and colourful fall foliage and has been widely planted as a potential biomass or oil crop and as an ornamental. Sapium is naturalized from the Gulf Coast of Texas to the Atlantic Coast of North Carolina. It aggressively displaces native plants and forms monospecific stands within decades of its appearance in a prairie (Bruce et al. 1997). In the Gulf Coast, much coastal prairie has been converted to Sapium woodland thickets (Bruce et al. 1997; Grace 1998).

Because Sapium differs from the dominant plants at our site in many ways other than being an alien species, pairing it with an ecologically similar native species in experiments can give a better understanding of the mechanisms of invasion (Barrett \& Richardson 1986; Mack 1996; Keane \& Crawley 2002). By using both Sapium and an appropriate native tree species in our experiments, we help control for differences between Sapium and other native plants that are unrelated to their alien or native status. This is especially important in a prairie because Sapium is a woody species competing with herbaceous species. Ideally, the native and alien species would be congeners (Barrett \& Richardson 1986; Mack 1996), but Sapium sebiferum is the only member of its genus in the Gulf Coast of Texas, and there is no native tree in the Euphorbiaceae in Texas (Hatch et al. 1990). We selected the native species most ecologically similar to Sapium that occurred at our site, namely Hackberry (Celtis laevigata Willd., Ulmaceae, 'Celtis' hereafter). Both Sapium and Celtis are insect pollinated and bird dispersed (Bush \& Van Auken 1986; Bruce et al. 1997). Both tend to grow in wetter sites and both species have the potential to grow rapidly. We have used Celtis successfully in a number of other studies examining the mechanisms of Sapium invasion (Rogers et al. 2000; Nijjer et al. 2002; Rogers \& Siemann 2002; Siemann \& Rogers 2003a). 
Positive feedbacks and woody plant invasions
We conducted two grassland field experiments with Sapium and Celtis seedlings to test the following predictions: (i) nitrogen fertilization will favour tree seedlings by alleviating soil nutrient limitation; (ii) shade will benefit tree seedlings by reducing competition from herbaceous vegetation; (iii) tree seedlings will perform better in the combination of nitrogen fertilization and shade than in other treatment combinations; and (iv) increasing light to tree seedlings without increasing it for herbaceous vegetation will increase the tree seedlings' growth.

\section{Methods}

\section{STUDY SITE}

The University of Houston Coastal Centre is a 374-ha research area located $c .50 \mathrm{~km}$ south-east of Houston, Texas, USA (Siemann \& Rogers 2003a). Historically, this site was mostly tallgrass prairie. Some areas have been invaded by Sapium while others have been protected from invasion by annual mowing. Mowed areas are dominated by graminoids, with Schizachyrium scoparium (Michx.) Nash, Spartina patens (Ait.) Muhl. and Tripsacum dactyloides (L.) L the main species. Forbs (main species: Helianthus angustifolius L., Agalinis heterophylla (Nutt.) Small ex Britt. \& A. Br., Euthamia leptocephala (T. \& G) Greene) and woody plants (14\% of cover; especially Rubus riograndis Bailey) are also abundant (unpublished data). Mowing was stopped in the area of our experiments for the duration of these studies. Average annual rainfall is $1070 \mathrm{~mm}$, distributed fairly evenly throughout the year. Average temperature is $20.9^{\circ} \mathrm{C}$. Soils are expansive Lake Charles Clay Vertisols (fine, montmorillonitic, thermic Typic Pelludert) with a $40-60 \%$ clay content (Anonymous 1988).

\section{NITROGEN AND SHADE EXPERIMENT}

We used a complete factorial design with 40 plots $(2.4 \mathrm{~m} \times 2.4 \mathrm{~m}$ with $2 \mathrm{~m}$ buffer zones between adjacent plots) that received three treatments: seedling species (four Celtis seedlings or four Sapium seedlings), fertilization (control or N), and shade (control or shade). The four seedlings were spaced evenly within each plot (square $0.8 \mathrm{~m}$ on a side, $0.8 \mathrm{~m}$ buffer to edge of plot).
Nitrogen fertilization plots received $8 \mathrm{~g} \mathrm{~m}^{-2}$ year $^{-1}$ of $\mathrm{N}$ applied as ammonium nitrate in May, June, July and August (i.e. $2 \mathrm{~g} \mathrm{~m}^{-2}$ each time). Cameron \& Spencer (1989) reported soil concentrations of nitrate in this field and adjacent tallow woodlands as 12 and 30 p.p.m., respectively. In another study in this field we found that the average nitrogen in the above-ground living prairie vegetation at peak standing crop was approximately $5 \mathrm{~g} \mathrm{~m}^{-2}$ (Lankau, Siemann \& Rogers, unpublished data). The fertilization treatments primarily tested the mechanism of woody plant facilitation by increasing nitrogen availability and are not intended as a precise experimental match to natural levels of soil nitrogen elevation by Sapium trees. Nonetheless, we used our best estimate of increased nitrogen availability (i.e. $8 \cong 5 \times[30-$ 12]/12) to guide the amount of ammonium nitrate added. Shade plots were covered by black polypropylene shade cloth ('95\% cloth', Stuewe \& Sons, Corvallis, Oregon, USA) mounted on a frame $150 \mathrm{~cm}$ above soil level and draped to $60 \mathrm{~cm}$ from the ground on the south side of the frame, $90 \mathrm{~cm}$ from the ground on the east and west sides and $120 \mathrm{~cm}$ from the ground on the north side. Light was reduced by $97 \%$ under the shade cloth (Table 1 ). The experiment was lightly watered eight times over two growing seasons to lessen possible confounding effects of uneven water distribution in the shade plots. The experiment ran for 526 days. We originally intended the experiment to run for 3 years but Sapium seedlings performed so well in the shade and nitrogen plots that several reached the height of the shade cloth by the end of the second year.

In November and December 1999, we collected seed from Sapium and Celtis trees at the University of Houston Coastal Centre. In January, seeds were planted into flats in an unheated greenhouse with open vent flaps. Seeds began to germinate in March, which is approximately the time the first seedlings appeared in the field. After a seed germinated, it was transferred to a Conetainer (Stuewe \& Sons) filled with $1 \mathrm{~cm}$ of peat moss and $12 \mathrm{~cm}$ of commercially available topsoil. Seedlings were grown in the glasshouse until they had two sets of true leaves, then grown outside under a $50 \%$ shade cloth to 'harden off'. Seedlings were transplanted into the field in April 2000.

We measured seedling survival and seedling height three times during each growing season. We used an
(C) 2003 British Ecological Society, Journal of Ecology, 91, 923-931
Table 1 Average light levels at the start of the nitrogen and shade experiment (shade cloths $n=20$, vegetation $n=20$ for each treatment) and the increased light experiment ( $n=15$ for each treatment). Absorbance values show the proportion of PAR that was absorbed by shade cloths and vegetation above the seedlings. Seedling percentage of PAR values are the average percentage of PAR above the shade cloths and vegetation that reached seedlings in different treatments of the two experiments. Means \pm standard errors

\begin{tabular}{|c|c|c|c|c|}
\hline & \multicolumn{2}{|c|}{ Nitrogen and shade experiment } & \multicolumn{2}{|c|}{ Increased light experiment } \\
\hline & Control & Shade & Control & Cage \\
\hline Shade cloth absorbance & - & $0.97 \pm 0.00$ & - & - \\
\hline Vegetation absorbance & $0.63 \pm 0.02$ & $0.64 \pm 0.02$ & $0.70 \pm 0.07$ & $0.25 \pm 0.01$ \\
\hline Seedling percentage of PAR & $37 \%$ & $0.9 \%$ & $30 \%$ & $75 \%$ \\
\hline
\end{tabular}


ACCUPAR linear PAR ceptometer (Decagon, Pullman, WA, USA) with an external sensor (LICOR, Lincoln, NE, USA) to measure light availability at the tops of seedlings. We took measurements twice during each growing season (June and August) at midday on cloudfree days. We estimated light availability as the average of the four measured values of light transmittance (TAU = PAR at seedling top/above canopy PAR $\times 100$ ). In the shade plots we took measurements at three heights: above the shade cloth, below the shade cloth but above the vegetation, and at the tops of seedlings. At the end of each growing season (October), we clipped the prairie vegetation at ground level in a $0.2-\mathrm{m}^{2}$ area $(20 \mathrm{~cm} \times 100 \mathrm{~cm})$ in each plot mid-way from the study seedlings to the edge of the plot. These vegetation samples were sorted to functional group (graminoid, forb, woody), dried and weighed. At the end of the experiment, we clipped the tree seedlings at ground level, dried them and weighed them.

\section{INCREASED LIGHT EXPERIMENT}

In a separate experiment, we used a factorial design with 30 seedlings of each species (Sapium or Celtis). Seedlings were individually planted in the centre of $1 \mathrm{~m} \times 1 \mathrm{~m}$ plots with $1 \mathrm{~m}$ buffer zones between adjacent plots and randomly assigned to control or increased light treatment. For seedlings assigned to the latter treatment, standard, commercially available $100 \mathrm{~cm}$ tall 'tomatocages' ( $36 \mathrm{~cm}$ in diameter at the top) were installed around the seedling. Background vegetation was trained outside the cages. As vegetation grew inside the cages, it was gently pulled outside. These cages increased the amount of light reaching the seedlings by a factor of 2.5 (Table 1). This experiment ran for 897 days.

The protocols for seed collection (late 1998), germination (early 1999), seedling preparation (spring 1999) and planting (April 1999) were the same as described above except for being a year earlier. Soils were very dry at the time of transplanting, so seedlings were lightly watered twice during the week after planting (in total each plot received $125 \mathrm{~mL}$ of water).

We measured the height and number of leaves on each seedling before transplanting. We checked seedling survival approximately monthly in the first growing season and bimonthly in the second and third growing seasons, which lasted from mid-March to midOctober. Three times during each growing season (April, July, October) we measured seedling height. Twice during each growing season we measured light availability as described above, and calculated an average value. At the end of the experiment (October 2001), we clipped seedlings at ground level, dried them and weighed them.

\section{Results}

We used ANOVA to examine the effect of treatments on survival (number of seedlings alive in a plot at the end
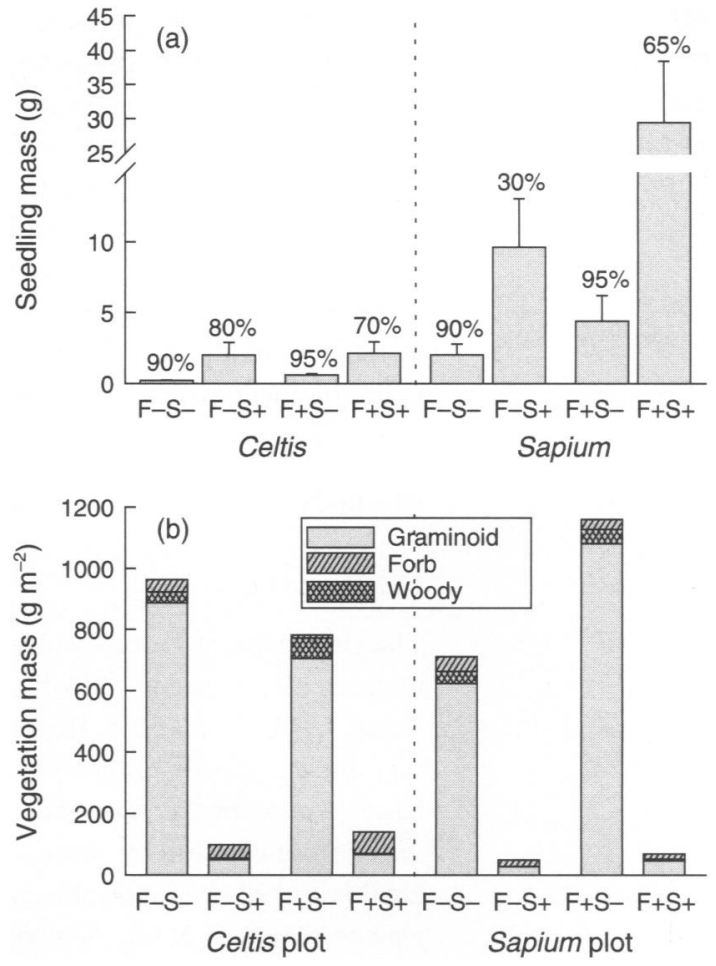

Fig. 1 (a) Mass of Celtis and Sapium seedlings in the shade and nitrogen fertilization experiment (average seedling mass per plot plus $1 \mathrm{SE}$ ). Numbers above each bar are the percentages of seedlings in that treatment surviving to the end of the experiment. (b) Above-ground mass of background vegetation in plots at the end of the experiment, separated by functional group. Treatments: $\mathrm{F}-=$ no fertilizer; $\mathrm{F}+=$ fertilized with nitrogen; $\mathrm{S}-=$ ambient light; $\mathrm{S}+=$ light reduction with shade cloth. Statistical results are in Table 2.

of the experiment). For this analysis, each plot is a single data point. In this experiment we would have 0.80 power to detect an effect size of 0.32 in this and other ANOVAs. The probability of Celtis seedling survival (84\%) was greater than the probability of Sapium survival (70\%, Fig. 1a, Table 2). Shade reduced seedling survival (no shade $92 \%$, shade $61 \%$ ) but nitrogen did not affect seedling survival (Fig. 1a, Table 2). The interaction term species $\times$ nitrogen $\times$ shade was significant (Table 2 ). Inspection of Fig. 1(a) suggests that shade caused greater decreases in Sapium survival in unfertilized plots. Single species ANOVAs supported this interpretation of the significance of ANOVA interaction terms; Sapium survival depended on shade $(P<0.01)$, nitrogen $\times$ shade $(P<0.05)$, but not nitrogen $(P=0.40)$, whereas Celtis survival was affected by shade $(P=0.08)$, but not by nitrogen $(P=0.80)$ or nitrogen $\times$ shade $(P=0.44)$.

We used ANOVA to examine the effect of treatments on seedling mass (average mass of surviving seedlings in a plot). Every main effect and interaction term was significant (Table 2, Fig. 1a). Sapium seedlings were larger than Celtis seedlings. Nitrogen and shade both increased seedling mass, especially for Sapium seedlings. The combination of nitrogen and shade had a greater than additive effect, particularly for Sapium seedlings. 
927

Positive feedbacks and woody plant invasions
Table 2 The effects of experimental treatments on tree seedlings and background vegetation (overall and by functional groups) a second growing season in the shade and nitrogen fertilization experiment. Mean values are shown in Fig. $1 .{ }^{*} 0.01 \leq P<0.05,{ }^{\star \star} 0$. ***0.0001 $\leq P<0.001, * * * * P<0.0001$

\begin{tabular}{|c|c|c|c|c|c|c|}
\hline \multirow[b]{2}{*}{ Term } & \multicolumn{2}{|c|}{ Seedling $\left(F_{1,32}\right)$} & \multicolumn{4}{|c|}{ Background vegetation mass $\left(F_{1,32}\right)$} \\
\hline & Survival & Mass & Overall & Graminoid & Forb & Woody \\
\hline Species & $6.3^{*}$ & $15.6^{* * *}$ & $<0.01$ & $<0.1$ & 0.2 & 0.4 \\
\hline Nitrogen & 0.3 & $8.8^{* *}$ & 0.9 & 0.8 & 0.6 & 0.1 \\
\hline Shade & $12.3^{* *}$ & $11.9^{* *}$ & $91.6 * * * *$ & $71.9 * * * *$ & $12.1^{* *}$ & 0.1 \\
\hline Species $\times$ Nitrogen & 0.7 & $8.7^{* *}$ & 3.2 & 3.1 & 0.1 & 0.1 \\
\hline Species $\times$ Shade & 1.4 & 8.0** & 0.5 & 0.2 & 0.1 & 2.2 \\
\hline Nitrogen $\times$ Shade & 1.4 & $6.8^{*}$ & 0.4 & 0.4 & 0.5 & 1 \\
\hline Species $\times$ Nitrogen $\times$ Shade & $4.7^{*}$ & $7.9 * *$ & 3.7 & 3 & 0.3 & 0.4 \\
\hline Model $F_{8,32}$ & $3.4^{* *}$ & $9.7 * * * *$ & $12.5 * * * *$ & $9.9 * * * *$ & 1.74 & 0.5 \\
\hline Model $r^{2}$ & 0.47 & 0.7 & 0.76 & 0.72 & 0.31 & 0.12 \\
\hline
\end{tabular}
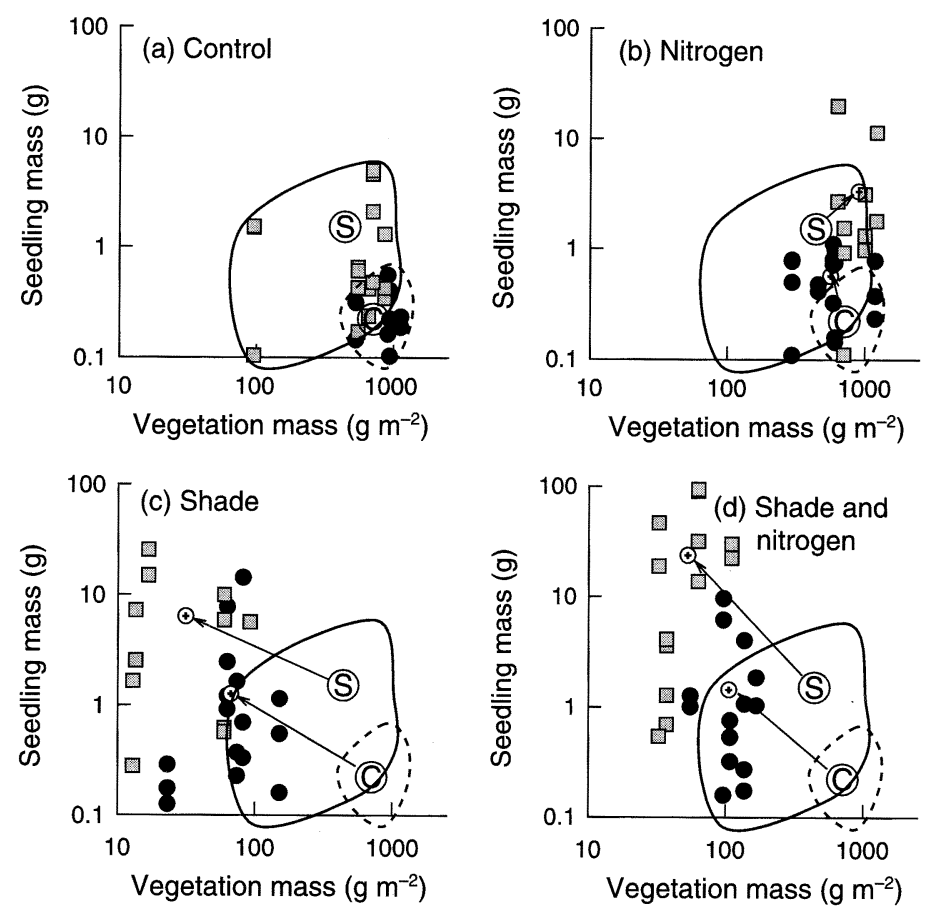

Fig. 2 Relationships between above-ground mass of background vegetation and seedling mass in different treatment combinations. ' $C$ ' and ' $S$ ' indicate the centre of the data points for Celtis (circles) and Sapium (squares), respectively, in control plots (average of plots). The dotted and solid lines indicate the range of values for all control Celtis and Sapium seedlings, respectively, and are shown for visual inspection. Arrows point from these values to the centres of the data distributions for Celtis and Sapium in other treatment combinations (averages of plots).

We used ANOVA to examine the effect of treatments on above-ground prairie vegetation mass. Above-ground vegetation mass was lower in shaded plots (Table 2, Fig. 1b). Biomass of graminoids and forbs, but not that of woody plants (predominantly Rubus), decreased with shade (separate ANOVAs for each functional group, Table 2). In these additional ANOvAs no other terms were significant.

The relationship of seedlings and surrounding biomass is shown in Fig. 2. When nitrogen was added, the positive response of tree seedlings appeared stronger than that of background vegetation, which is consistent with ANOVA results (Table 2). When plots were shaded, above-ground vegetation mass was strongly reduced whereas tree seedling mass increased. This is consistent with a significant main effect of shade on each variable in ANOVAs (Table 2). When plots were both fertilized and shaded, the mass of background vegetation decreased (shade main effect, Table 2) and tree seedling mass increased dramatically, especially for Sapium (nitrogen $\times$ shade, species $\times$ nitrogen $\times$ shade in Table 2 ).

\section{INCREASED LIGHT EXPERIMENT}

Seedlings in plots with cages holding back vegetation were, on average, more likely to survive to the end of the experiment, and were larger than those in control plots (Fig. 3a). Seedlings in plots without cages experienced 
928

E. Siemann \&

W. E. Rogers
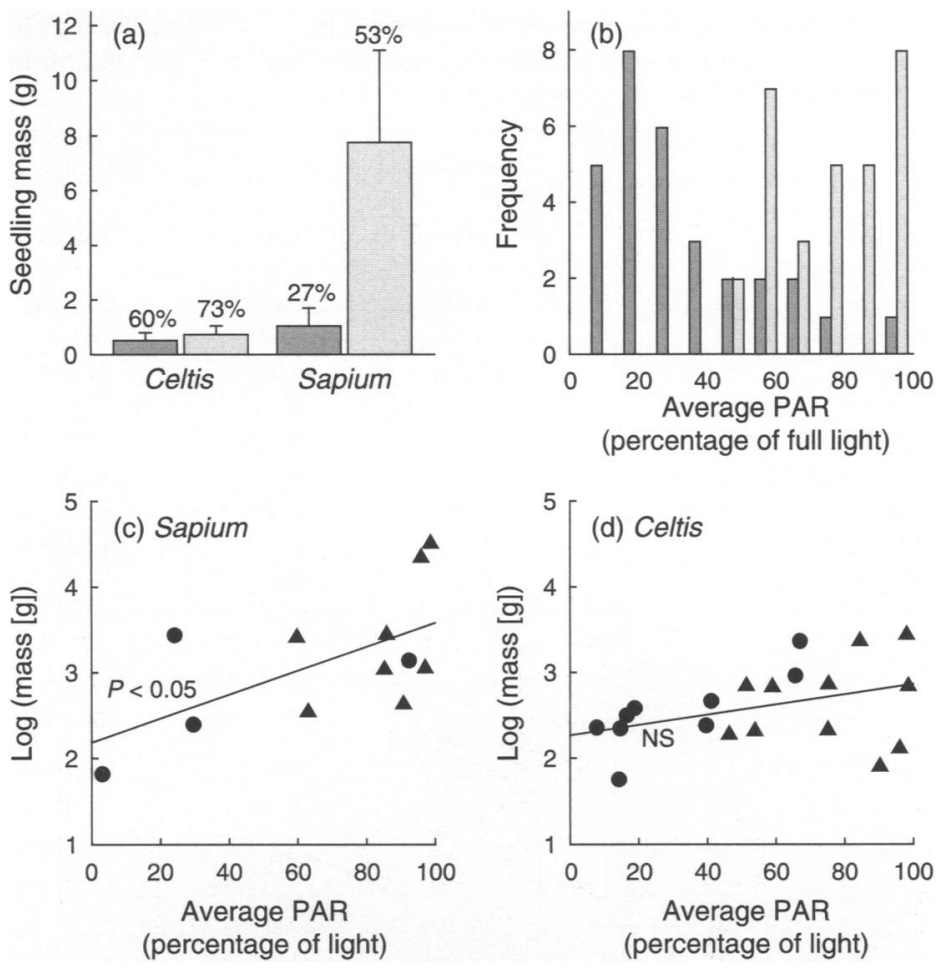

Fig. 3 Seedling mass (a) and light levels (b) in control plots (filled bars) and plots with prairie vegetation held back by cages (open bars) in the increased light experiment. Means +1 SE for mass. Numbers above the bars are the percentages of seedlings in that treatment surviving to the end of the experiment. Dependence of Sapium (c) and Celtis (d) mass on average light levels in the increased light experiment (circles $=$ control, triangles $=$ vegetation held back). More statistical details of regressions are in the results section.

a wide range of light conditions whereas those in plots with cages all experienced high light (Fig. 3b). Therefore, rather than perform a categorical logistic regression and an ANOvA to test for the effects of light cage treatment on seedling survival and growth, respectively, we performed regressions for each species using the average amount of light each seedling received as a continuous predictor. The odds of Sapium seedlings surviving to the end of the experiment increased significantly with light (logistic regression, coefficient $=0.036, P<0.05$ ). This coefficient means that the amount of light reduction required for the odds of death to be twice as likely as for a seedling in full light is $19 \%(\ln 0.5 / 0.036)$. Sapium mass (log transformed to achieve normality) increased significantly with light availability $(\log [$ mass $]=2.186+$ $0.014 \times$ TAU, $r^{2}=0.36, P<0.05$; Fig. $3 c$ c). Celtis odds of survival $(P=0.49)$ and seedling mass $(P=0.09$, Fig. 3d) were independent of light.

\section{Discussion}

\section{EFFECTS OF SHADE}

Shading grassland plots increased the growth of seedlings of both the alien tree Sapium sebiferum and the native tree Celtis laevigata (Table 2, Figs 1,2). This is consistent with the premise that light reductions in the vicinity of pioneer trees could be responsible for the unusually high success of tree seedlings that have been observed to recruit near established trees in grasslands (Scholes \& Archer 1997; Weltzin \& McPherson 1999; Van Auken 2000; Teague et al. 2001). More specifically, reductions in light in the vicinity of the first established Sapium trees could favour Sapium seedlings in competition with herbaceous vegetation in grasslands they are invading. In this experiment it is not likely that reduced light availability is indirectly influencing woody plant invasion by increasing water availability, as it appears to in some arid environments (e.g. Belsky 1994; Scholes \& Archer 1997; Burke et al. 1998; Wilson 1998). The increased growth and survival was an effect of light per se (Wilson 1998; Weltzin \& McPherson 1999).

One mechanism whereby lowered light levels could facilitate woody seedling survival is by reducing harmful effects of high light levels such as those of photoinhibition (Alves et al. 2002). If this mechanism were responsible for greater growth at low light levels compared with ambient light below the herbaceous layer (Table 2, Figs 1a,2), Sapium and Celtis should perform less well at light levels higher than this ambient light level. However, in our field experiment with increased light Sapium grew larger with increasing light levels up to $100 \%$ light (Fig. 3c), and growth of Celtis was not significantly affected by a wide range of light levels (Fig. 3d). A number of short-term pot studies demonstrate equivalent or better performance of Sapium and/ or Celtis at higher light levels in the absence of competition. In an experiment with Celtis and Sapium grown
Ecological Society, 91, 923-931 
929

Positive feedbacks and woody plant invasions

(C) 2003 British

Ecological Society, Journal of Ecology, 91, 923-931 in pots at $37 \%$ and $12 \%$ light levels, mass at 105 days was independent of light for each species (Rogers \& Siemann 2002). When grown in pots for 120 days at $100 \%$, $53 \%, 20 \%$ and $5 \%$ light, Sapium seedlings were largest in the highest light levels (Jones \& McLeod 1990). In general, Sapium and Celtis are most successful in highlight conditions (Bush \& Van Auken 1986; Bruce et al. 1997). The greater growth of Sapium and Celtis at lower light levels in the present shade experiment (Table 2, Figs 1,2) is therefore not likely to be the result of reduced harmful effects of light.

Reduced herbaceous mass in shaded conditions suggests that reduced competitive interference in shaded conditions is a more likely explanation (Table 2, Figs $1 \mathrm{a}, 2)$. We found lower background above-ground vegetation mass in shaded plots, particularly for graminoids and forbs (Table 2, Fig. 1b). Such reductions in herbaceous biomass are associated with lower intensities of below-ground competition that have the potential to more than offset the reduced availability of light (Casper \& Jackson 1997; Scholes \& Archer 1997; Wilson 1998; Levine 1999). Such an effect of lowered light levels on the relative intensities of above- and below-ground competition is not unique to tree invasions of Texas grasslands. A positive feedback via light preemption may be a general feature of grassland-forest transitions if reducing light availability favours woody seedlings with low root: shoot ratios in competition with grasses with high root : shoot ratios (Tilman 1990; Wilson 1993; Wilson 1998), or favours C3 plants in competition with C4 grasses (Scholes \& Archer 1997). In other words, the indirect positive effect of pioneer trees suppressing grasses that compete strongly with woody seedlings may be larger than the direct negative competitive effect of pioneer trees on the woody seedlings (Levine 1999). In some cases, pioneer trees may favour seedlings of other woody species as much or more than conspecific seedlings (Teague et al. 2001).

\section{EFFECTS OF NITROGEN}

Nitrogen fertilization increased the growth of Celtis and Sapium seedlings without changing the mass of background vegetation (Table 2, Figs 1,2), presumably by increasing the concentrations of available nitrogen in the soil. Higher soil fertility is often associated with lower intensities of below-ground competition and higher intensities of above-ground competition (Tilman 1988; Casper \& Jackson 1997) though theory (Grime 1979) and empirical evidence (Casper \& Jackson 1997; Peltzer et al. 1998; Rajaniemi 2002) suggest that fertility and relative intensities of above- and below-ground competition may be unrelated. In some systems, the mechanism whereby the importance of above-ground competition increases with fertility appears to be an increase in aboveground mass and higher overall utilization of light by the plant community (Tilman 1988; Casper \& Jackson 1997). However, we found no effect of nitrogen addition on above-ground prairie vegetation mass (Table 2, Fig. 1a).
In some studies, the lack of a relationship between importance of above-ground competition and productivity has been attributed to strong competition for water (Peltzer et al. 1998) but our grasslands receive more rainfall than the maximum at which this is thought to occur (Burke et al. 1998).

Our results are consistent with asymmetric competition for soil nitrogen (Casper \& Jackson 1997), with herbaceous vegetation having strong competitive effects on woody seedlings. The response of woody species to experimental additions of nitrogen is predicted to be greater than that of herbaceous vegetation, for which limitation by nitrogen availability may be less severe. Direct facilitation due to nitrogen enrichment by trees may not generalize to all tree and grass systems but may only characterize systems with trees with nitrogen-rich foliage that are invading $\mathrm{C} 4$ dominated grasslands. Trees may also indirectly increase nitrogen availability by changing physical conditions to favour more rapid organic matter decomposition (Köchy \& Wilson 1997; Prescott 2002).

The effect of the combination of shade and fertilizer on tree seedling performance was more than additive (Table 2, Figs 1A,2), especially for Sapium. The benefit to tree seedlings from increases in nitrogen was much larger when interference from herbaceous vegetation was also reduced by shading. In Minnesota grasslands, shading caused no reduction in plant biomass, whereas addition of $3 \mathrm{~g} \mathrm{~m}^{-2}$ year $^{-1}$ of $\mathrm{N}$ caused significant increases (Tilman 1990). The relative importance of indirect facilitation of woody seedling success via light reduction, and direct facilitation via nitrogen increases may differ between grasslands that differ in relative limitation by light and nitrogen.

\section{ALIEN VS. NATIVE TREE SEEDLING PERFORMANCES}

Sapium outperformed Celtis in all resource conditions even though Celtis is one of the fastest growing native trees in Texas (Harcombe et al. 1999). Further, Sapium rapidly invades grasslands that are only slowly invaded by native woody species (Smeins et al. 1992; Harcombe et al. 1993). Although mortality is relatively high for seedlings in the herbaceous understorey (Carson \& Root 1999), Sapium's relatively high annual mortality risk may be offset by its extremely short residence time in the understorey.

Lack of herbivory may be responsible for Sapium's unusually high performance and invasiveness. Compared with Celtis and other native tree species, Sapium suffers low levels of insect damage as a seedling (Rogers \& Siemann 2003; Siemann \& Rogers 2003a). In addition, Celtis seedlings are browsed by vertebrates more frequently than Sapium seedlings (Siemann \& Rogers 2003a). Indeed, in the experiments reported here we also found that Celtis seedlings were more frequently browsed than Sapium seedlings (shade experiment: Celtis $22.5 \%$ browsed at least once during the experiment, 
Sapium 5\%; light increase experiment: Celtis 13\%, Sapium $3 \%$ ). Finally, genotypes of Sapium collected locally in Texas, which were used in these experiments, have been shown to have significantly higher growth rates, earlier and greater seed production but lower foliar tannin concentrations than genotypes from its native range in Asia (Siemann \& Rogers 2001; 2003b,c). The evolution of increased competitive ability hypothesis (Blossey \& Nötzold 1995), which postulates an evolutionary mechanism for reallocation of resources from defence to growth in response to low herbivory, is consistent with these patterns for invasive and native genotypes of Sapium.

The factors responsible for the superiority of Sapium seedlings in unmanipulated conditions may also explain why the benefit of light reductions and nitrogen additions is greater for Sapium seedlings than for Celtis seedlings (Figs 1 and 2). However, facilitative effects of pioneer trees on tree seedling recruitment cannot explain the successful establishment of the earliest trees in these grasslands. Sapium is able to establish from seed in Texas grasslands even in the absence of major disturbances (Bruce et al. 1997; Grace 1998). In this context, resource feedbacks may be important in influencing the dynamics of the transition from grassland to Sapium forest, but are perhaps less important in determining whether an unmanaged grassland will eventually become a Sapium forest (Taylor et al. 1990; Davis et al. 2000). Nonetheless, understanding the mechanisms and dynamics of invasion may be crucial for managing Sapium and other invasive woody plants in grasslands.

\section{Acknowledgements}

We thank G. Aumann, T. Becker, J. Hammer, J. Ferris, M. Hartley, J. Keay, R. Lankau and S. Nijjer for assistance, Duane Peltzer for comments, the University of Houston Coastal Center for access, and the US National Science Foundation (DEB-9981654) for support.

\section{References}

Alves, P., Magalhaes, A.C.N. \& Barja, P.R. (2002) The phenomenon of photoinhibition of photosynthesis and its importance in reforestation. Botanical Review, 68, 193-208.

Anonymous (1988) Soil Survey of Galveston County, Texas. Soil Conservation Service, Temple, Texas.

Archer, S., Scifres, C. \& Bassham, C.R. (1988) Autogenic succession in a subtropical savanna: conversion of grassland to thorn woodland. Ecological Monographs, 58, 111-127.

Bakker, J.P. \& Berendse, F. (1999) Constraints in the restoration of ecological diversity in grassland and heathland communities. Trends in Ecology and Evolution, 14, 63-68.

Barrett, S.C.H. \& Richardson, B.J. (1986) Genetic attributes of invading species. Ecology of Biological Invasions (eds R.H. Groves \& J.J. Burdon), pp. 21-33. Cambridge University Press, Melbourne, Australia.

Belsky, A.J. (1994) Influences of trees on savanna productivity: tests of shade, nutrients and tree-grass competition. Ecology, 75, 922-932.

Berlow, E.L., D’Antonio, C.M. \& Reynolds, S.A. (2002) Shrub expansion in montane meadows: the interaction of local-scale disturbance and site aridity. Ecological Applications, 12, 1103-1118.
Blossey, B. \& Nötzold, R. (1995) Evolution of increased competitive ability in invasive nonindigenous plants: a hypothesis. Journal of Ecology, 83, 887-889.

Bragg, T.B. \& Hulbert, L.C. (1976) Woody plant invasion of unburned Kansas bluestem prairie. Journal of Range Management, 29, 19-24.

Briggs, J.M., Hoch, G.A. \& Johnson, L.C. (2002) Assessing the rate, mechanisms and consequences of the conversion of tallgrass prairie to Juniperus virginiana forest. Ecosystems, 5, 578-586.

Bruce, K.A., Cameron, G.N., Harcombe, P.A. \& Jubinsky, G. (1997) Introduction, impact on native habitats, and management of a woody invader, the Chinese tallow tree, Sapium sebiferum (L.) Roxb. Natural Areas Journal, 17, 255-260.

Burke, I.C., Lauenroth, W.K., Vinton, M.A., Hook, P.B., Kelly, R.H., Epstein, H.E. et al. (1998) Plant-soil interactions in temperate grasslands. Biogeochemistry, 42, 121-143.

Bush, J.K. \& Van Auken, O.W. (1986) Light requirements of Acacia smallii and Celtis laevigata in relation to secondary succession on floodplains of South Texas. American Midland Naturalist, 115, 118-122.

Callaway, R.M., Nadkarni, N.M. \& Mahall, B.E. (1991) Facilitation and interference of Quercus douglasii on understory productivity in central California. Ecology, 72, 1484-1499.

Cameron, G.N. \& Spencer, S.R. (1989) Rapid leaf decay and nutrient release in a Chinese tallow forest. Oecologia, $\mathbf{8 0}$, 222-228.

Carson, W.P. \& Root, R.B. (1999) Top-down effects of insect herbivores during early succession: influence on biomass and plant dominance. Oecologia, 121, 260-272.

Casper, B.B. \& Jackson, R.B. (1997) Plant competition underground. Annual Review of Ecology and Systematics, 28, $545-570$.

Connell, J.H. \& Slatyer, R.O. (1977) Mechanisms of succession in natural communities and their role in community stability and organization. American Naturalist, 111, 1119 1144.

Davis, M.A., Grime, J.P. \& Thompson, K. (2000) Fluctuating resources in plant communities: a general theory of invasibility. Journal of Ecology, 88, 528-534.

Dukes, J.S. \& Mooney, H.A. (1999) Does global change increase the success of biological invaders? Trends in Ecology and Evolution, 14, 135-139.

Goldberg, D.E. \& Barton, A.M. (1992) Patterns and consequences of interspecific competition in natural communities - a review of field experiments with plants. American Naturalist, 139, 771-801.

Grace, J.B. (1995) In search of the holy-grail - explanations for the coexistence of plant-species. Trends in Ecology and Evolution, 10, 263-264.

Grace, J.B. (1998) Can prescribed fire save the endangered coastal prairie ecosystem from Chinese tallow invasion? Endangered Species Update, 15, 70-76.

Grime, J.P. (1979) Plant Strategies and Vegetation Processes. Wiley, London.

Harcombe, P.A., Cameron, G.N. \& Glumac, E.G. (1993) Aboveground net primary productivity in adjacent grassland and woodland on the coastal prairie of Texas. Journal of Vegetation Science, 4, 521-530.

Harcombe, P.A., Hall, R.B.W., Glitzenstein, J.S., Cook, E.S., Krusic, P., Fulton, M. et al. (1999) Sensitivity of Gulf Coast forests to climate change. Vulnerability of coastal wetlands in the southeastern United States: climate change research results. Biology Science Report USGS/BRD/BSR-1998 0002 (eds G. Gunterspergen \& B.A. Varain), pp. 45-66. United States Geological Survey, Washington, DC, USA.

Hatch, S.L., Ghandi, K.N. \& Brown, L.E. (1990) A Checklist of the Vascular Plants of Texas. Texas Agricultural Experiment Station, College Station, Texas. 
931

Positive feedbacks and woody plant invasions
Hibbard, K.A., Archer, S., Schimel, D.S. \& Valentine, D.W. (2001) Biogeochemical changes accompanying woody plant encroachment in a subtropical savanna. Ecology, 82, 1999-2011.

Huenneke, L.F., Hamburg, S.P., Koide, R., Mooney, H.A. \& Vitousek, P.M. (1990) Effects of soil resources on plant invasion and community structure in California serpentine grassland. Ecology, 71, 478-491.

Jones, R.H. \& McLeod, K.W. (1990) Growth and photosynthetic responses to a range of light environments in Chinese tallowtree and Carolina ash seedlings. Forest Science, 36, 851-862.

Jutila, H.M. \& Grace, J.B. (2002) Effects of disturbance on germination and seedling establishment in a coastal prairie grassland: a test of the competitive release hypothesis. Journal of Ecology, 90, 291-302.

Keane, R.M. \& Crawley, M.J. (2002) Exotic plant invasions and the enemy release hypothesis. Trends in Ecology and Evolution, 17, 164-170.

Köchy, M. \& Wilson, S.D. (1997) Litter decomposition and nitrogen dynamics in aspen forest and mixed-grass prairie. Ecology, 78, 732-739.

Köchy, M. \& Wilson, S.D. (2001) Nitrogen deposition and forest expansion in the northern Great Plains. Journal of Ecology, 89, 807-817.

Lambers, H., Chapin, F.S. \& Pons, T.L. (1998) Plant Physiological Ecology. Springer, New York.

Levine, J.M. (1999) Indirect facilitation: evidence and predictions from a riparian community. Ecology, $\mathbf{8 0}$, 1762-1769.

Li, X. \& Wilson, S.D. (1998) Facilitation among woody plants establishing in an old field. Ecology, 79, 2694-2705.

Mack, R.N. (1996) Predicting the identity and fate of plant invaders: emergent and emerging approaches. Biological Conservation, 78, 107-121.

Mooney, H.A. (1972) The carbon balance of plants. Annual Review of Ecology and Systematics, 3, 315-346.

Nijjer, S., Lankau, R.A., Rogers, W.E. \& Siemann, E. (2002) Effects of temperature and light on Chinese tallow (Sapium sebiferum) and Texas sugarberry (Celtis laevigata) seed germination. Texas Journal of Science, 54, 63-68.

Peltzer, D.A., Wilson, S.D. \& Gerry, A.K. (1998) Competition intensity along a productivity gradient in a low-diversity grassland. American Naturalist, 151, 465-476.

Prescott, C.E. (2002) The influence of the forest canopy on nutrient cycling. Tree Physiology, 22, 1193-1200.

Rajaniemi, T.K. (2002) Why does fertilization reduce plant species diversity? Testing three competition-based hypotheses. Journal of Ecology, 90, 316-324.

Rogers, W.E., Nijjer, S., Smith, C.L. \& Siemann, E. (2000) Effects of resources and herbivory on leaf morphology and physiology of Chinese tallow (Sapium sebiferum) tree seedlings. Texas Journal of Science, 52S, 43-56.

Rogers, W.E. \& Siemann, E. (2002) Effects of simulated herbivory and resource availability on native and invasive exotic tree seedlings. Basic and Applied Ecology, 3, 297 307.
Rogers, W.E. \& Siemann, E. (2003) Effects of simulated herbivory and resources on Chinese tallow tree (Sapium sebiferum, Euphorbiaceae) invasion of native coastal prairie. American Journal of Botany, 90, 241-247.

Sage, R.F. \& Pearcy, R.W. (1987) The nitrogen use efficiency of C-3 and C-4 plants. 2. Leaf nitrogen effects on the gasexchange characteristics of Chenopodium album (L.) and Amaranthus retroflexus (L.). Plant Physiology, 84, 959-963.

Scholes, R.J. \& Archer, S.R. (1997) Tree-grass interactions in savannas. Annual Review of Ecology and Systematics, 28, 517-544.

Siemann, E. \& Rogers, W.E. (2001) Genetic differences in growth of an invasive tree species. Ecology Letters, 4, 514-518.

Siemann, E. \& Rogers, W.E. (2003a) Herbivory, disease, recruitment limitation and the success of alien and native tree species. Ecology, 84, 1489-1505.

Siemann, E. \& Rogers, W.E. (2003b) Increased competitive ability of an invasive tree may be limited by an invasive beetle. Ecological Applications, 13, in press.

Siemann, E. \& Rogers, W.E. (2003c) Reduced resistance of invasive varieties of the alien tree Sapium sebiferum to a generalist herbivore. Oecologia, 135, 451-457.

Smeins, F.E., Diamond, D.D. \& Hanselka, C.W. (1992) Coastal prairie. Natural Grasslands: Introduction and Western Hemisphere. Ecosystems of the World, Vol. 8A (ed. R.T. Coupland), pp. 269-290. Elsevier, Amsterdam.

Taylor, D.R., Aarssen, L.W. \& Loehle, C. (1990) On the relationship between $\mathrm{R} / \mathrm{K}$ selection and environmental carrying-capacity - a new habitat templet for plant lifehistory strategies. Oikos, 58, 239-250.

Teague, W.R., Dowhower, S.L., Whisenant, S.G. \& FloresAncira, E. (2001) Mesquite and grass interference with establishing redberry juniper seedlings. Journal of Range Management, 54, 680-684.

Tilman, D. (1988) Plant Strategies and the Dynamics and Structure of Plant Communities. Princeton University Press, Princeton.

Tilman, D. (1990) Constraints and tradeoffs: toward a predictive theory of competition and succession. Oikos, 58, 3-15.

Tilman, D. \& Pacala, S. (1993) The maintenance of species diversity in plant communities. Species Diversity in Ecological Communities (eds R. Ricklefs \& D. Schluter), pp. 13-25. University of Chicago Press, Chicago.

Van Auken, O.W. (2000) Shrub invasions of North American semiarid grasslands. Annual Review of Ecology and Systematics, 31, 197-215.

Weltzin, J.F. \& McPherson, G.R. (1999) Facilitation of conspecific seedling recruitment and shifts in temperate savanna ecotones. Ecological Monographs, 69, 513-534.

Wilson, S.D. (1993) Belowground competition in forest and prairie. Oikos, 68, 146-150.

Wilson, S.D. (1998) Competition between grasses and woody plants. Population Biology of Grasses (ed. G. Cheplick), pp. 231-254. Cambridge University Press, Cambridge.

Received 31 October 2002

revision accepted 8 July 2003 